\title{
Simple procedure for determination of the carbon content in silica-supported materials
}

- Nguyen Tien Giang

- Hoang Hanh Uyen

- Nguyen Khac Manh

- Nguyen Huy Du

- Nguyen Anh Mai

University of Science, VNU-HCM

(Received on $30^{\text {th }}$ June 2015, accepted on $2^{\text {nd }}$ December 2016)

\section{ABSTRACT}

A simply and accurate analytical method was developed to determination the carbon content in silica-supported materials. The principle of this method was to oxidize sample by a strong oxidant like potassium dichromate to produce carbon dioxide and this gas is absorbed into an alkaline solution for subsequent titration. The repeatability and the recovery of this method fell into the required range $(\% R S D<1.3 \%$ and 98 $102 \%$ in recovery) of AOAC International. The chloride content of up to $100 \mathrm{mg}$ did not give any influence. The developed procedure was applied to determine the carbon content in octadecylmodified silica samples.

Keywords: Carbon, wet oxidation, silica-supported materials

\section{INTRODUCTION}

Currently many silica-supported materials are widely used in various applications [1-3]. To evaluate characterizations of the material, its compositions are usually determined. Of elements to be determined, carbon is the most popular since it presents in all organic compounds.

Methods of sample combustion for determination the carbon content have been developed since 1970s with high recovery and repeatability. The principle was to oxidize carbon compounds to produce carbon dioxide and capture it in an absorbent towards weight or volumetric methods [4-6]. So far, modernly instrumental methods have been applied to carbon analysis such as NMR or using elemental analysis technique. These methods are rapid and accurate, however their tremendous disadvantage is too expensive to equip for all laboratories.
In this work a method of wet combustion for determination of the carbon content in silicasupported materials was developed and evaluated. The method was also applied to our 10 research samples.

\section{MATERIALS AND METHODS}

\section{Materials}

$\mathrm{K}_{2} \mathrm{Cr}_{2} \mathrm{O}_{7}$ and $\mathrm{NaOH}$ were products of Merck. $\mathrm{H}_{2} \mathrm{SO}_{4}, \mathrm{H}_{3} \mathrm{PO}_{4}$ and $\mathrm{HCl}$ were purchased from Labscan. Silica (particle diameter 40-60 $\mu \mathrm{m}$, mean pore diameter $60 \AA$, specific surface area $500 \mathrm{~m}^{2} / \mathrm{g}$ ), was purchased from Scharlau. Trimethoxyoctadecyl silane (TMOS) $90 \%$ and stearic acid $(98.5 \%)$ were obtained from SigmaAldrich. Ten research samples of octadecylsupported silica material were prepared by silanization [7].

\section{Trang 162}




\section{Apparatus}

Apparatus for determination of the carbon content is illustrated in Fig. 1.

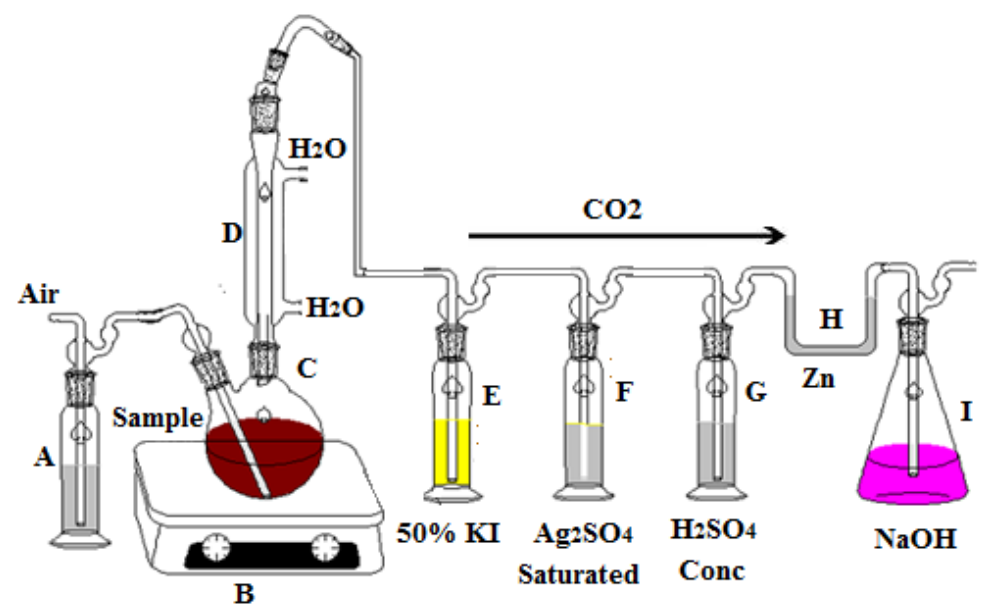

Figure 1. Apparatus for determination of carbon content

The aeration vessel A $(25 \mathrm{~cm}$ in height, $4 \mathrm{~cm}$ in diameter) is connected to on air compressor and a quarter is filled with $\mathrm{CaO}$ to remove carbon dioxide from the incoming air. The vessel $\mathrm{A}$ is connected to $250-\mathrm{mL}$ two-neck flat bottom flask $\mathrm{C}$ to contain sample and oxidation reagents. The electric stove B can heat up to $400{ }^{\circ} \mathrm{C}$. When the digestion flask $\mathrm{C}$ is heated, $\mathrm{CO}_{2}$ as well as acid fume, $\mathrm{Cl}_{2} \ldots$ are resulted in. The condenser $\mathrm{D}(25$ $\mathrm{cm}$ in height, $4 \mathrm{~cm}$ in diameter) is attached to the flask $\mathrm{C}$ to condense the acid fume. The next is the trap chain with 4 traps. Among them traps E, F and $G$ are the same aeration vessel $(25 \mathrm{~cm}$ in height, $4 \mathrm{~cm}$ in diameter). The trap $\mathrm{E}$ is half filled with $50 \%$ aqueous solution of potassium iodide to absorb chloride by-products. The trap $\mathrm{F}$ is also half filled with saturated solution of $\mathrm{Ag}_{2} \mathrm{SO}_{4}$. Trap $G$ contains not more than one third concentrated $\mathrm{H}_{2} \mathrm{SO}_{4}$ for absorbing the humidity. Any acid fume escaping the trap $\mathrm{G}$ is captured at the $\mathrm{U}$ tube $\mathrm{H}$ (40 $\mathrm{cm}$ in length, $1 \mathrm{~cm}$ in diameter) containing 2-cm height $\mathrm{Zn}$ particles. Finally, the conical flask I containing $\mathrm{NaOH}$ is connected to the system to absorb the resulted $\mathrm{CO}_{2}$.

\section{Procedure}

To the $\mathrm{CO}_{2}$ absorbing flask $\mathrm{I}$, add $25 \mathrm{~mL}$ of $1.0 \mathrm{M} \mathrm{NaOH}$ solution and 2-3 drops of phenolphthalein ( $1 \%$ in ethanol) and place it in the position in the system.

To the digestion flask $\mathrm{C}$, add a precise amount of silica-supported materials that contain 15-120 mg of carbon, continuously add 4-5 g of $\mathrm{K}_{2} \mathrm{Cr}_{2} \mathrm{O}_{7}$ and approximately $30 \mathrm{~mL}$ of $\mathrm{H}_{2} \mathrm{SO}_{4}: \mathrm{H}_{3} \mathrm{PO}_{4}$ mixture $(3: 2)(\mathrm{v} / \mathrm{v})$, respectively. Immediately assemble it to the position in the system.

Turn on the incoming air at the velocity of 1 $\mathrm{mL} / \mathrm{min}$ and use "check leak" solution to check all the joints to make sure that there are no gaps.

Successively heat the digestion flask $\mathrm{C}$ at about $150{ }^{\circ} \mathrm{C}$ for $1 \mathrm{~h}$ and then at $200{ }^{\circ} \mathrm{C}$ for 30 $\min$.

Unbind the flask I off the system, rinse its aeration tube several times with de-ionized water and titrate it with $1 \mathrm{M} \mathrm{HCl}$ solution until the solution converts from pink to colorless.

Blank sample is prepared as the procedure above with sample as silica. 


\section{Calculation}

$$
\mathrm{mc}(\mathrm{mg})=\left(\mathrm{V}_{\mathrm{Bl}}-\mathrm{V}_{\mathrm{S}}\right) \times \mathrm{C}_{\mathrm{HCl}} \times 12
$$

And

$$
\mathrm{C}(\%)=\frac{\left(\mathrm{V}_{\mathrm{B1}}-\mathrm{V}_{\mathrm{S}}\right) \times \mathrm{CHCl}_{\mathrm{HC}} \times 12}{\mathrm{~m}(\mathrm{~g}) \times 10}
$$

Where:

$\mathrm{m}_{\mathrm{C}}$ : Weight of carbon in sample specimen $(\mathrm{mg})$

$\mathrm{V}_{\mathrm{Bl}}$ : Volume of $\mathrm{HCl}$ solution to titrate absorption solution of blank sample $(\mathrm{mL})$

$\mathrm{V}_{\mathrm{S}}$ : Volume of $\mathrm{HCl}$ solution to titrate absorption solution of sample $(\mathrm{mL})$

$\mathrm{C}_{\mathrm{HCl}}$ : Concentration of $\mathrm{HCl}$ solution (M) after calibrating with standard oxalic acid

$\mathrm{m}$ : Weight of sample specimen $(\mathrm{g})$

\section{RESULTS AND DISCUSSION}

\section{Precision and trueness}

Determinations were carried out to examine the precision of this method. Since the goal of this development was to determine the carbon content in silica-supported materials, those usually are saturated chains of 3,8 or 18 carbons bonded to the silica surface, and there is no standard material, stearic acid was selected as the standard for the method validation.

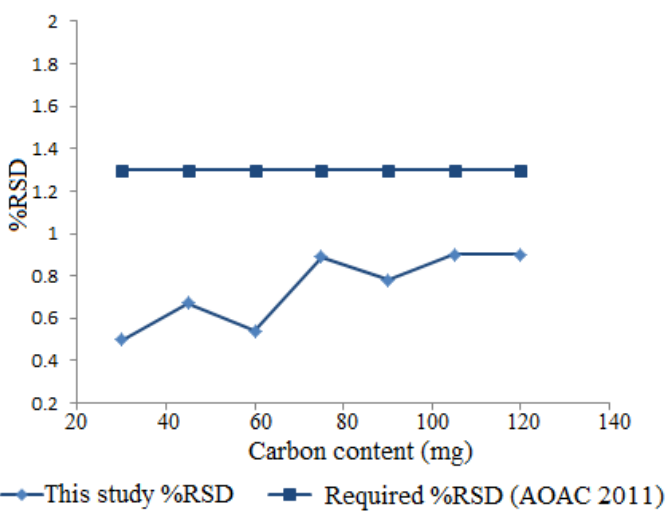

Figure 2. Comparision of \% RSDs at different carbon amounts between our method and the AOAC regulation $(n=5)$

The standards with various carbon contents from 30 to $120 \mathrm{mg}$ were analyzed five times independently for each level. All \% RSD at different carbon levels were lower than those required by AOAC International (Fig. 2).

\section{Trueness}

The precision validation part of these experiments, the recovery of this method was calculated through the ratio of practical and theoretical carbon amount. The results showed that recovery of the whole procedure is in the range from 98 to $102 \%$ which is required by AOAC International [8].

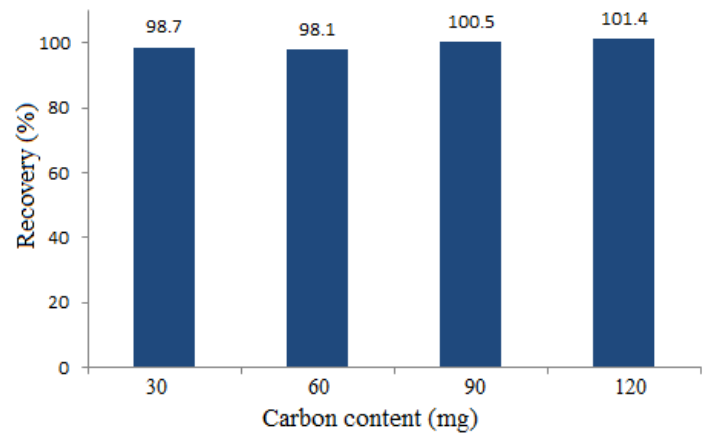

Figure 3. Recovery of carbon content at different amounts

As a result it can be stated that this method was accurate since both the precision and trueness complied with the international regulation.

\section{Chloride interference}

Chloride is considered the interference in wet combustion method. Because some silicasupported materials may contain chloride, its effect was investigated. The influence of increasing amounts of chloride (up to $100 \mathrm{mg}$ ) added as sodium chloride to the ca. $30 \mathrm{mg}$ of carbon containing standard samples are presented in Table 1. It can be concluded that the chloride mass of less than $100 \mathrm{mg}$ did not have effect on the carbon content since both recovery and \% $\mathrm{RSD}$ values fell into the required range of AOAC international.

\section{Trang 164}


Table 1. Repeatablity and recovery of the method

\begin{tabular}{|c|c|c|c|c|}
\hline \multirow{2}{*}{$\begin{array}{c}\text { Added } \\
\text { chloride }(\mathrm{mg})\end{array}$} & \multicolumn{2}{|c|}{ Carbon (\%) } & \multirow{2}{*}{$\begin{array}{c}\text { Recovery } \\
(\%)\end{array}$} & $\begin{array}{c}\text { RSD } \\
(\%)\end{array}$ \\
\cline { 2 - 3 } & Theoretical value & Experimental value & 99.6 & 0.68 \\
\hline 25 & 76.0 & 75.7 & 100.5 & 0.98 \\
\hline 50 & 76.0 & 76.4 & 101.4 & 0.11 \\
\hline 75 & 76.0 & 77.1 & 101.7 & 1.15 \\
\hline 100 & 76.0 & 77.3 & & \\
\hline
\end{tabular}

When the contents of the digestion flask are heated, chloride is converted to $\mathrm{CrO}_{2} \mathrm{Cl}_{2}$, which is deposited in on the cooler part of the flask and condenser. However when the digestion mixture is brought to boiling, $\mathrm{CrO}_{2} \mathrm{Cl}_{2}$ disappears since it decomposes at $180-190{ }^{\circ} \mathrm{C}$ which is lower than the boiling point $\left(210{ }^{\circ} \mathrm{C}\right)$ of the mixture, and releases $\mathrm{Cl}_{2}$ [5]. This $\mathrm{Cl}_{2}$, traces of $\mathrm{CrO}_{2} \mathrm{Cl}_{2}$ and $\mathrm{HCl}$ fume react with the contents of "chlorine and acid fume" traps ( $\mathrm{E}$ and F). Therefore, chloride by-products could not reach the $\mathrm{CO}_{2}$ absorbing part to affect it.

$$
\begin{gathered}
\mathrm{Cl}_{2}+2 \mathrm{I}^{-} \rightarrow 2 \mathrm{Cl}^{-}+\mathrm{I}_{2} \\
\mathrm{Ag}^{+}+\mathrm{Cl}^{-} \rightarrow \mathrm{AgCl} \downarrow
\end{gathered}
$$

Determination of real samples

10 samples (S1-S10) were synthesized they are octadecyl containing material on silica support with trimethoxyoctadecyl silane reagent. Experiments were optimized so that the reaction yield was the highest. Table 2 showed the carbon content of resulted products when some conditions such as temperature, catalyst were changed.

Table 2. Carbon content in some synthesized samples

\begin{tabular}{|c|c|c|c|}
\hline $\begin{array}{c}\text { Sample } \\
\text { No }\end{array}$ & $\begin{array}{c}\text { Carbon } \\
(\%)\end{array}$ & $\begin{array}{c}\text { Sample } \\
\text { No }\end{array}$ & $\begin{array}{c}\text { Carbon } \\
(\%)\end{array}$ \\
\hline S1 & 6.4 & S6 & 11.2 \\
\hline S2 & 7.8 & S7 & 12.8 \\
\hline S3 & 8.5 & S8 & 13.2 \\
\hline S4 & 10.2 & S9 & 14.2 \\
\hline S5 & 10.8 & S10 & 14.6 \\
\hline
\end{tabular}

\section{CONCLUSION}

In this study, a simple and accurate analytical method for determination of the carbon content in silica-supported materials was developed and validated. With high trueness, precision as well as cheap cost the method could be applied to all laboratories. This method can also be used for determination of the carbon content in different types of sample without further development [4$6]$. 


\section{Phương pháp đơn giản xác định hàm lượng carbon trong các vật liệu trên nền silica}

- Nguyễn Tiến Giang

- Hoàng Hạnh Uyên

- Nguyễn Khắc Mạnh

- Nguyễn Huy Du

- Nguyễn Ánh Mai

Trường Đại học Khoa học Tự nhiên, ĐHQG-HCM

\section{TÓM TẮT}

Một phưong pháp phân tích đơn giản và chinh xác đã được phát triển cho việc xác định hàm luợng carbon trong các vật liệu trên nền silica. Nguyên tắc chung của phuoong pháp là sủ dụng chất oxy hóa mạh nhu $\mathrm{K}_{2} \mathrm{Cr}_{2} \mathrm{O}_{7}$ để oxy hóa mẫu, tạo ra khí $\mathrm{CO}_{2}$. Khí $\mathrm{CO}_{2}$ sinh ra được hấp thu vào dung dịch kiềm và chuẩn độ lại để xác định hàm luợng carbon. Độ lạp lại và hiệu suất

thu hồi của toàn bộ quá trình ở trong khoảng yêu cầu của AOAC International (\% RSD $<1,3 \%$ và độ lạp lại 98-102\%). Hàm luợng chlorine lên tới $100 \mathrm{mg}$ không gây ảnh huơong đến kết quả. Quy trình này được áp dụng để xác định hàm luợng carbon trong các mẫu trong nghiên cưu tổng hợp vật liệu silica biến tính octadecyl.

Tù khóa: carbon, oxi hóa uoót, vật liệu trên giá mang silica

\section{REFERENCES}

[1]. S.K. Kundu, S.K. Roy, Aminopropyl silca gel as solid support for the preparation of glycolipid immunoadsorbent and purification of antibodies, Journal of Lipid Research, 20, 825-833 (1979).

[2]. X. Liu, A.V. Bordunov, C.A. Pohl, Preparation and evaluation of a hydrolytically stable amide-embeded stationary phase, Journal of Chromatography A, 1119, 128-134 (2006).

[3]. K.D. Lork, K.K. Unger, J.N. Kinkel, Role of the functional group in $n$ octyldimethylsilanes of $\mathrm{C} 8$ reversed phase silica parkings for high performance liquid chromatography, Journal of Chromatography A, 352, 199-211(1986)

[4]. R.C. Dalal, Calibration of proposed wetcombustion procedure with dried combustion method for the determination of total carbon in soils, Analyst, 104 151-154 (1979).

[5]. W.O. Enwezor, A.H. Cornfield, Determination of total carbon in soils by wet combustion, Journal of the Science of Food and Agriculture, 16, 277-280 (1965).

[6]. J. Kosaka, C. Honda, A. Iseki, A new rapid and accurate method for determination of carbon in soils, Soil Science and Plant Nutrition, 5, 77-83 (1959).

[7]. B. Buszewski, L. Nondek, A. Jurášek, D. Berek, Preparation of silanized silica with high ligand density. The effect of sliane structure, Chromatographia, 23, 442-446 (1987).

[8]. Standard format and guidance for AOAC Standard Method Performance Requirement, AOAC International (2011).

\section{Trang 166}

